\title{
Betacyanins and Betaxanthins in Cultivated Varieties of Beta vulgaris L. Compared to Weed Beets
}

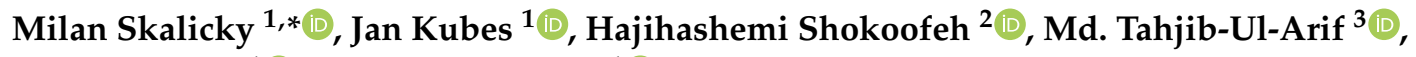 \\ Pavla Vachova ${ }^{1}$ (D) and Vaclav Hejnak ${ }^{1}$ (D) \\ 1 Department of Botany and Plant Physiology, Faculty of Agrobiology, Food and Natural Resources, \\ Czech University of Life Sciences Prague, 16500 Prague, Czech Republic; kubes@af.czu.cz (J.K.); \\ vachovap@af.czu.cz (P.V.); hejnak@af.czu.cz (V.H.) \\ 2 Plant Biology Department, Faculty of Science, Behbahan Khatam Alanbia University of Technology, \\ Khuzestan 47189-63616, Iran; hajihashemi@bkatu.ac.ir \\ 3 Department of Biochemistry and Molecular Biology, Faculty of Agriculture, \\ Bangladesh Agricultural University, Mymensingh 2202, Bangladesh; tahjib@bau.edu.bd \\ * Correspondence: skalicky@af.czu.cz; Tel.: +420-22438-2520
}

Academic Editor: Krystian Marszałek

Received: 21 October 2020; Accepted: 16 November 2020; Published: 18 November 2020

\begin{abstract}
There are 11 different varieties of Beta vulgaris L. that are used in the food industry, including sugar beets, beetroots, Swiss chard, and fodder beets. The typical red coloration of their tissues is caused by the indole-derived glycosides known as betalains that were analyzed in hypocotyl extracts by UV/Vis spectrophotometry to determine the content of betacyanins (betanin) and of betaxanthins (vulgaxanthin I) as constituents of the total betalain content. Fields of beet crops use to be also infested by wild beets, hybrids related to $B$. vulgaris subsp. maritima or B. macrocarpa Guss., which significantly decrease the quality and quantity of sugar beet yield; additionally, these plants produce betalains at an early stage. All tested B. vulgaris varieties could be distinguished from weed beets according to betacyanins, betaxanthins or total betalain content. The highest values of betacyanins were found in beetroots 'Monorubra' $(9.69 \mathrm{mg} / 100 \mathrm{~mL})$ and 'Libero' $(8.42 \mathrm{mg} / 100 \mathrm{~mL})$. Other beet varieties contained less betacyanins: Sugar beet 'Labonita' $0.11 \mathrm{mg} / 100 \mathrm{~mL}$; Swiss chard 'Lucullus,' $0.09 \mathrm{mg} / 100 \mathrm{~mL}$; fodder beet 'Monro' $0.15 \mathrm{mg} / 100 \mathrm{~mL}$. In contrast with weed beets and beetroots, these varieties have a ratio of betacyanins to betaxanthins under 1.0, but the betaxanthin content was higher in beetcrops than in wild beet and can be used as an alternative to non-red varieties. Stability tests of selected varieties showed that storage at $22^{\circ} \mathrm{C}$ for $6 \mathrm{~h}$, or at $7{ }^{\circ} \mathrm{C}$ for $24 \mathrm{~h}$, did not significantly reduce the betalain content in the samples.
\end{abstract}

Keywords: beetroot; beetcrops; weedbeet; betalains; spectrophotometry; storage

\section{Introduction}

The EU is the world's leading producer of sugar beets, with a cultivation area of 1.74 million hectares (2018) - approximately 50\% of the global production. The Czech Republic has a long history of growing sugar beets and, upon admission to the EU, has contributed $4.4 \%$ of the EU production. The cultivation area was 157 thousand hectares in 1980, 50 thousand hectares in 2008, and 65 thousand hectares nowadays with a yield of $71.2 \mathrm{t} / \mathrm{ha}$ [1]. Other beet crops, such as fodder beets, Swiss chard, and beetroots, are also produced, but are of lesser importance. Beta vulgaris L. is grown especially for the large succulent taproot, which contains many organic and inorganic compounds depending on the cultivated variety, as well as large amounts of sucrose in the case of sugar beets. Swiss chard is the exception, because it is the leaves rather than the roots that are harvested and they have a high content of vitamins and antioxidant phenolic compounds [2]. 
Beside sucrose, primary metabolites, and various organic acids and vitamins, plants in the genus Beta synthesize secondary metabolites known as betalains. These pigmented compounds were previously mistaken for anthocyanins, another important plant substance imparting a red color to the tissues. Both types of metabolites are soluble in water and they are localized in vacuoles. However, their biosynthesis and structure are different and several authors have claimed mutual exclusivity of betalains and anthocyanins in plants [3].

Betalains are composed of two basic groups: Red betacyanins and yellow betaxanthins. Betanin from the former group is the typical B. vulgaris metabolite and there are about 17 different betacyanin compounds described in this plant. In contrast, only about 12 betaxanthins have been identified here, and vulgaxanthin I is the primary compound in beets $[4,5]$. In the food industry, certain parts of the amaranth and fruits from the Opuntia and Hylocerasus cacti are utilized as a source of betalains too, and betanin itself serves as a dye (E162) in milk products [6]. Regarding the occurrence of betalains, they are in almost whole Caryophyllales order and some genera of fungi [7]. The number of identified pigments from this group is increasing with better analytical methods and technologies [8] and about 180 different betacyanin pigments have already been described; as in Bougainvillea glabra, where 146 betacyanins were detected [9].

These secondary metabolites are derived from the polar aromatic amino acid, tyrosine, through the action of enzymes to produce dihydroxyphenylalanine (L-DOPA) and betalamic acid, the precursor compound for synthesis of both subgroups of betalains. Despite the involvement of phenylpropanoids, deamination does not occur during biosynthesis of betalamic acid. The amino group nitrogen is incorporated into the heterocyclic ring. Because of the system of conjugated double bonds, betalamic acid acts as a chromophore with a bright yellow color. Through a related biosynthetic pathway, a single carbonyl group can be added with other amino acids, amines, or cyclo-DOPA, from tyrosine, which affects the final coloration resulting in the synthesis of betaxanthins (amino acid adducts) or betacyanins (cyclo-DOPA). The conjugation with cyclo-DOPA shifts the absorption maximum from $480 \mathrm{~nm}$ (yellow) to $540 \mathrm{~nm}$ (purple) [10]. Betaxanthin shows hypso- or batho-chromic shifts, because conjugates of amines have lower absorption maxima $\left(\mathrm{A}_{\max }\right)$ than their amino acid analogues [11]. The presence of nitrogen in the molecule and the absence of a basic chromane core are the main structural differences between these plant metabolites and anthocyanins. Betalains can also form glycosidic bonds, such as with betanidin and its glycoside betanin; the molecules can be acylated as well $[6,12]$.

Thanks to their structure, betalains have significant antioxidant activity that can be stronger than ascorbic acid and other molecules with similar effect [13]. This activity is dependent on the origin of pigments, because plants (genus Beta, Amaranthus, Celosia) from family Amaranthaceae synthesizes betacyanin metabolites with various structural modifications such as different position of hydroxyl groups, bonded sugar units and their acylation. Molecule of betacyanin or betaxanthin group has importance as well and the latter achieved better antioxidant results, which was also related to more hydroxyl and imino groups [14]. Nevertheless, the red constituent had better results in correlation with antioxidant activity than betaxanthins in the case of juices from red beet [15].

However, betalains are relatively sensitive to environmental factors such as heat and high or low $\mathrm{pH}$ and oxygen, which can cause degradation of the metabolites during the processing of plant material [16]. Still, betalains are more stable in the $\mathrm{pH}$ range of 3 to 7 than anthocyanins, which have an optimum $\mathrm{pH}$ range of 5 to 6 . Outside of the optimal values, there is a shift in the absorbance spectra [17] because strongly acidic or alkaline conditions cause structural changes in the molecules of betalains $[18,19]$.

The terms weed beet and wild beet are given to the most common hybrids between the cultured and wild forms of B. vulgaris L. with varying genetic compositions [20]. Populations of wild Beta L. species are found throughout Europe, including the Czech Republic. The first occurrence was reported in 1970 from Great Britain, where fertile annual beets were found, and they have existed as weeds in commercial sugar beet (B. vulgaris L. Group Altissima) fields in Europe [21] for many years, 
causing substantial reductions in crop size. Thus, significant losses to sugar yield and quality result if these wild plants are not removed [22]. The annual wild beet plants grow much faster and have more seed production cycles throughout the season than sugar beets making them more competitive for light and nutrients. Years of unmanaged, infested fields have increased the weed seed bank, resulting in continuous wild beet growth throughout the season [20,23]. Previous research [20,24] identified these populations as either B. vulgaris L. subsp. maritima (L.) Arcang. or B. macrocarpa Guss. This distinction is critical because $B$. vulgaris subsp. maritima will readily cross hybridize with cultivated sugar beets, while B. macrocarpa rarely does. In Europe, populations of B. vulgaris subsp. maritima have a wide distribution as far west as the Canary Islands and moving north along the Atlantic coast and Baltic Sea $[22,24]$.

Weed beets have distinct physiological and morphological traits, though they may not be manifested in all plants at the same time. Phenotypically the traits include a one-year life cycle, multi-germicity, root branching in older plants and plagiotropic growth [25]. Inter-row occurrence of weed beets is common but does depend on the agriculture practices during the growing period. The goal would be to identify the weed beets early and remove them; however, if these plants are grown in rows, their determination may not be easy [26]. The red color of the hypocotyls of young weed beets can be used to identify them, or the fact that they bolt earlier than sugar beets. An effective early identification method for weed beets could, thus, contribute significantly to the detection of infestation of weed beets and their removal.

\section{Results}

\subsection{Betalain Content in Hypocotyls of Different Beet Genotypes}

The betalain content, as well as the concentration of betacyanins and betaxanthins, was determined in four different varieties of sugar beet (LSB, ESB, CSB, and MSB), fodder beets (MFB) and Swiss chard (LSC). The varieties of beetroots were evaluated separately because of the high concentration of betacyanins in their extracts (the abbreviations of tested genotypes—see Table 1).

Table 1. Experimental beet crops and weed beets used.

\begin{tabular}{ccccc}
\hline Abbr. & $\begin{array}{c}\text { Taxon } \\
\text { Beta } \text { vulgaris L. }\end{array}$ & Variety Name & Crop & Variety Attributes \\
\hline LSB & Altissima Group & Labonita & Sugar beet & A2011 |2|D|m \\
ESB & Altissima Group & Esperanza & Sugar beet & A2004 |2|D|m \\
CSB & Altissima Group & Caruso & Sugar beet & A2005 |2|D|m \\
MSB & Altissima Group & Merak & Sugar beet & A2003 |2|D|m \\
MBR & Vulgaris Group & Monorubra & Beetroot & A1987 \\
DBR & Vulgaris Group & Detroit Dark Red 2 & Beetroot & A1997 \\
LBR & Vulgaris Group & Libero & Beetroot & A1994 \\
PBR & Vulgaris Group & Pablo & Beetroot & A1994 | hybrid \\
KBR & Vulgaris Group & Kahira & Beetroot & A2003 \\
LSC & Cicla Group & Lucullus & Swiss chard & A1973 \\
MFB & Rapacea Group & Monro & Fodder beet & A1994 $|4|-\mid m$ \\
WB* & subsp. maritima $* *$ & - & Weed beet & hybridizes withcultivated beets \\
\hline
\end{tabular}

${ }^{*} \mathrm{WB}_{\mathrm{G}}$-weed beets green parts $\mid \mathrm{WB}_{\mathrm{R}}$-weed beets red parts ${ }^{* *}$ or Beta macrocarpa Guss. |Abbr., abbreviation; $\mathrm{A}$, admission in national list status; 2 , diploid; 4 , tetraploid; D, double hybrid; $\mathrm{m}$, monogerm (Source: European Commission [27]).

The level of these pigments in the prepared extracts was compared with samples from extracts from red and green hypocotyls samples of WB. The varieties of MBR and LBR had the highest concentration of betanin equivalents of all tested beets (Figure 1A). The fodder beets, MFB, contained more betacyanins than Swiss chard or sugar beets (Figure 2A), where the concentration of betacyanins was the lowest in MSB. There was strong evidence that the content of these pigments in samples of cultivated plants is distinguishable from that in extracts of WB. The only exception was fodder beet, MFB; however, 
this beet had more betacyanins than $\mathrm{WB}_{\mathrm{G}}$. The variety, MBR, had the highest content of betaxanthins compared to other beetroots. (Figure 1B). All tested extracts of beet crops were distinguishable from $\mathrm{WB}_{\mathrm{R}}$ and $\mathrm{WB}_{\mathrm{G}}$ in spite of low content of betaxanthins, as they had significantly higher content of these pigments, with the exception of sugar beet, MSB (Figure 2B). As expected, MBR and LBR had the highest levels of total betalains in their hypocotyls (Figure 1C) and their extracts were darker colored than the other beets (Figure 3A). Betalains were present at greater levels in samples of MFB (Figure 2C); however, there was no significant difference in the content of these metabolites between ESB/LSC/LSB and MSB/CSB. In contrast with other beet crops, the latter varieties were indistinguishable from extracts of WB in the case of total betalains.

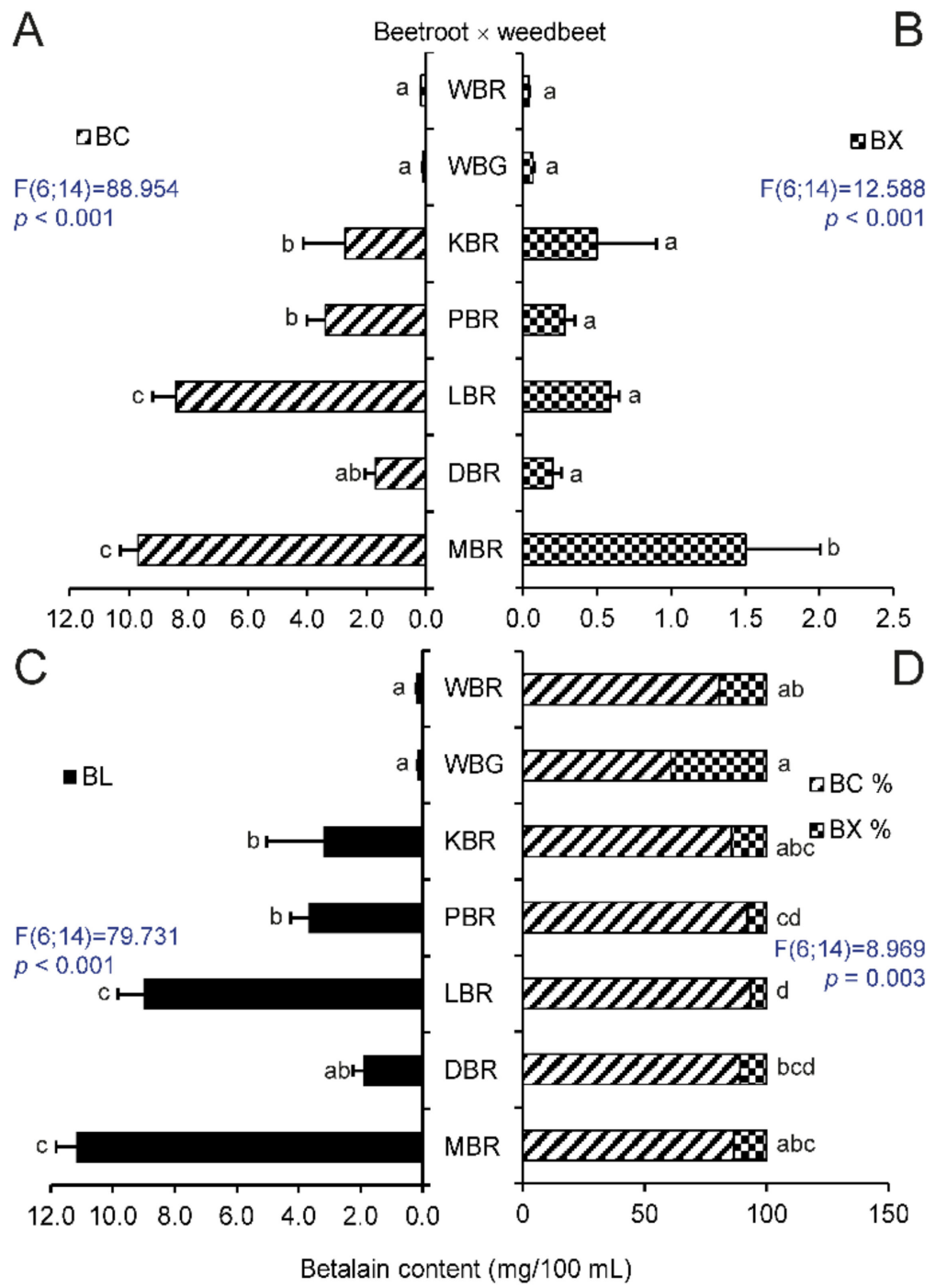

Figure 1. Contents of beet pigments. (A) BC, betacyanins, (B) BX, betaxanthins, and (C) BL, betalains, in $\mathrm{mg} / 100 \mathrm{~mL}$, and the $\mathrm{BC} / \mathrm{BX}$ percentage ratio (D) in hypocotyl extracts from Beta vulgaris Vulgaris Group and B. vulgaris subsp. maritima. Abbreviations of specific genotypes refer to names stated in Table 1. Bars with the same letter indicate means that are not significantly different at the 0.05 probability level according to Tukey post hoc test. Horizontal lines denote standard errors.

A recalculation of the percentage of the content of specific compounds showed that the ratio of the pigments could not be used to distinguish between individual beet crops or sugar beets. Nevertheless, all beet crops were distinguishable from WB (Figure 2D). There was also a significant difference between $\mathrm{WB}_{\mathrm{G}}$ and all samples of beetroots, while no difference was seen between $\mathrm{WB}_{\mathrm{R}}$ and $\mathrm{KBR}$ and MBR (Figure 1D). 


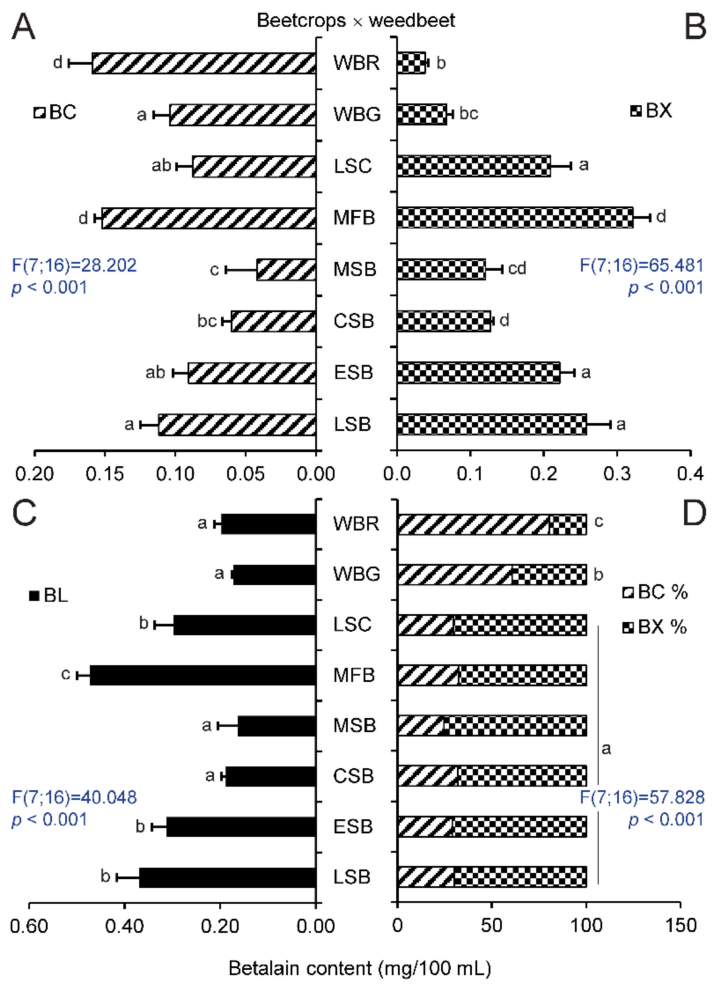

Figure 2. Contents of beet pigments. (A) BC, betacyanins, (B) BX, betaxanthins, and (C) BL, betalains, in $\mathrm{mg} / 100 \mathrm{~mL}$, and the $\mathrm{BC} / \mathrm{BX}$ percentage ratio (D) in hypocotyl extracts from Beta vulgaris Altissima, Cicla and Rapacea Group and B. vulgaris subsp. maritima. Abbreviations of specific genotypes refer to names stated in Table 1 . Bars with the same letter indicate means that are not significantly different at the 0.05 probability level according to Tukey post hoc test. Horizontal lines denote standard errors.
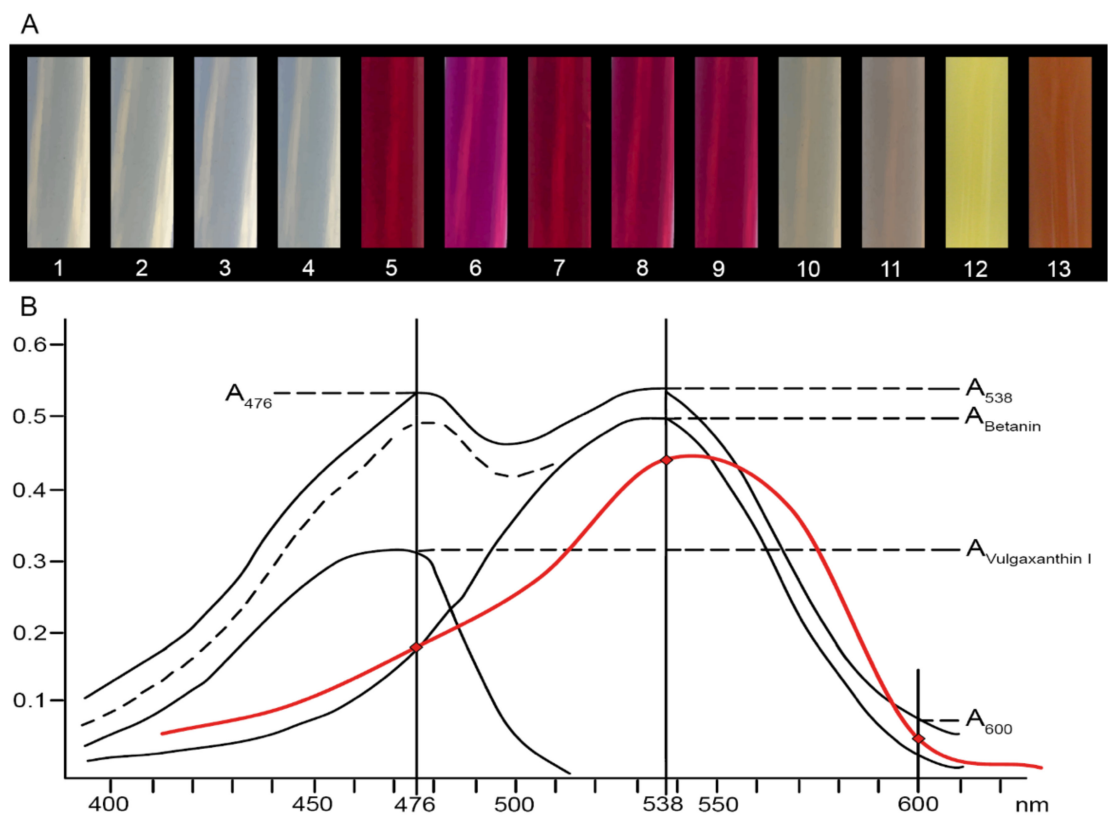

Figure 3. Extracts from Beta vulgaris hypocotyls. (A) Extracts of particular B. vulgaris L. genotypes and weed beet (1. LSB|2. ESB|3. CSB|4. MSB|5. MBR|6. DBR|7. LBR|8. PBR|9. KBR|10. LSC|11. MFB|12. WBG|13. WBR-see Table 1). (B) Absorbance data of beetroot extracts from B. vulgaris Vulgaris Group-Libero/Monorubra (red) showing the absorption spectra of betanin and vulgaxanthin (Elbe, 2001). 


\subsection{Effect of Storage on Betalain Content}

Storage of MFB and LBR at $22{ }^{\circ} \mathrm{C}$ for $6 \mathrm{~h}$ did not significantly change the content of betalains or its individual constituents (Figure 4A,B). LBR maintained significantly higher betacyanin levels in comparison with betaxanthins, while MFB showed the opposite effect. The differences in pigmentation among the varieties were clearly visible. LSC samples stored at $7^{\circ} \mathrm{C}$ contained significantly more betaxanthins and betacyanins as well (Figure 4C) after $24 \mathrm{~h}$. However, higher concentrations of betaxanthins were not measured in beetroot samples, DBR, PBR, and KBR at the same conditions (Figure 4D). The prevalence of betacyanins was proven in the case of all extracts except for LSC, where betaxanthins were the primary pigment. This result further demonstrates the significant difference between beetroots and Swiss chard.

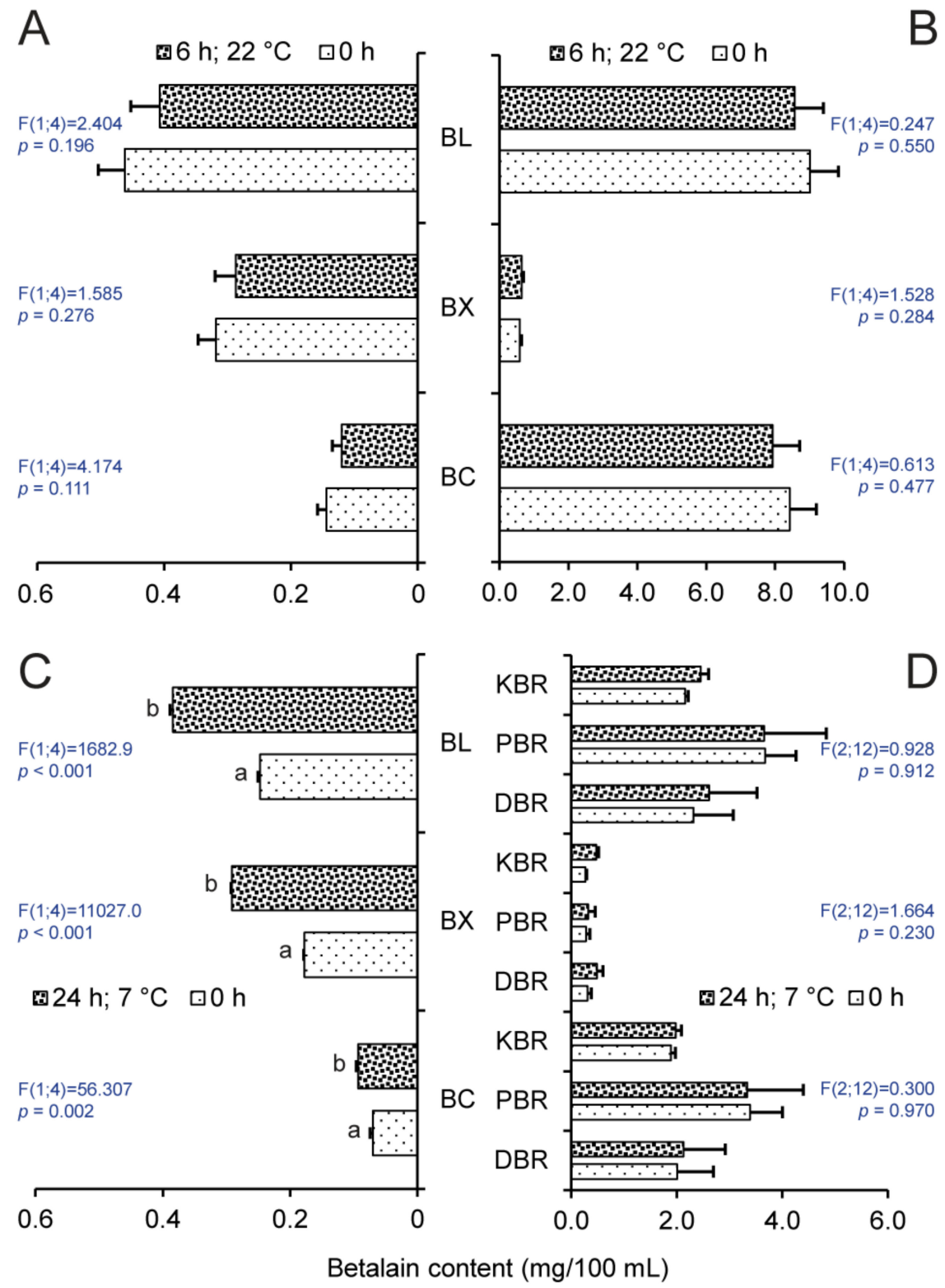

Figure 4. Contents of betacyanins (BC), betaxanthins (BX), and betalains (BL) in $\mathrm{mg} / 100 \mathrm{~mL}$ in extracts from (A) fodder beet, MFB, (B) beetroot, LBR, (C) Swiss chard, LSC, and (D) and beetroots KBR, PBR, and DBR, stored at different temperatures. Abbreviations of specific genotypes refer to names stated in Table 1. Bars with the same letter indicate means that are not significantly different at the 0.05 probability level according to Tukey post hoc test. Horizontal lines denote standard errors. 
Analysis of metabolites in WB confirmed that the red stems of sample III had the highest content of betanin equivalents (Figure 5A). Keeping samples in the freezer at $-18^{\circ} \mathrm{C}$ reduced the betacyanin levels by half. In one frozen sample of stem III, the content was reduced to one-third in comparison with samples held at $20^{\circ} \mathrm{C}$. The concentrations of betaxanthins were not different between individual WB samples; however, stem II had a significantly lower content of the metabolite after storage in the freezer (Figure 5B). The highest total betalain content was found in stem III and freezing decreased this by about $50 \%$ (Figure 5C). Regarding the percentage values of individual betalain components, stems I and II had similar concentrations of measured compounds and freezer storage did not change their ratio (Figure 5D). However, the content of betacyanins decreased in sample III, while a higher percentage level of betaxanthins was the result of its minimal degradation at low temperature (Figure 5B).

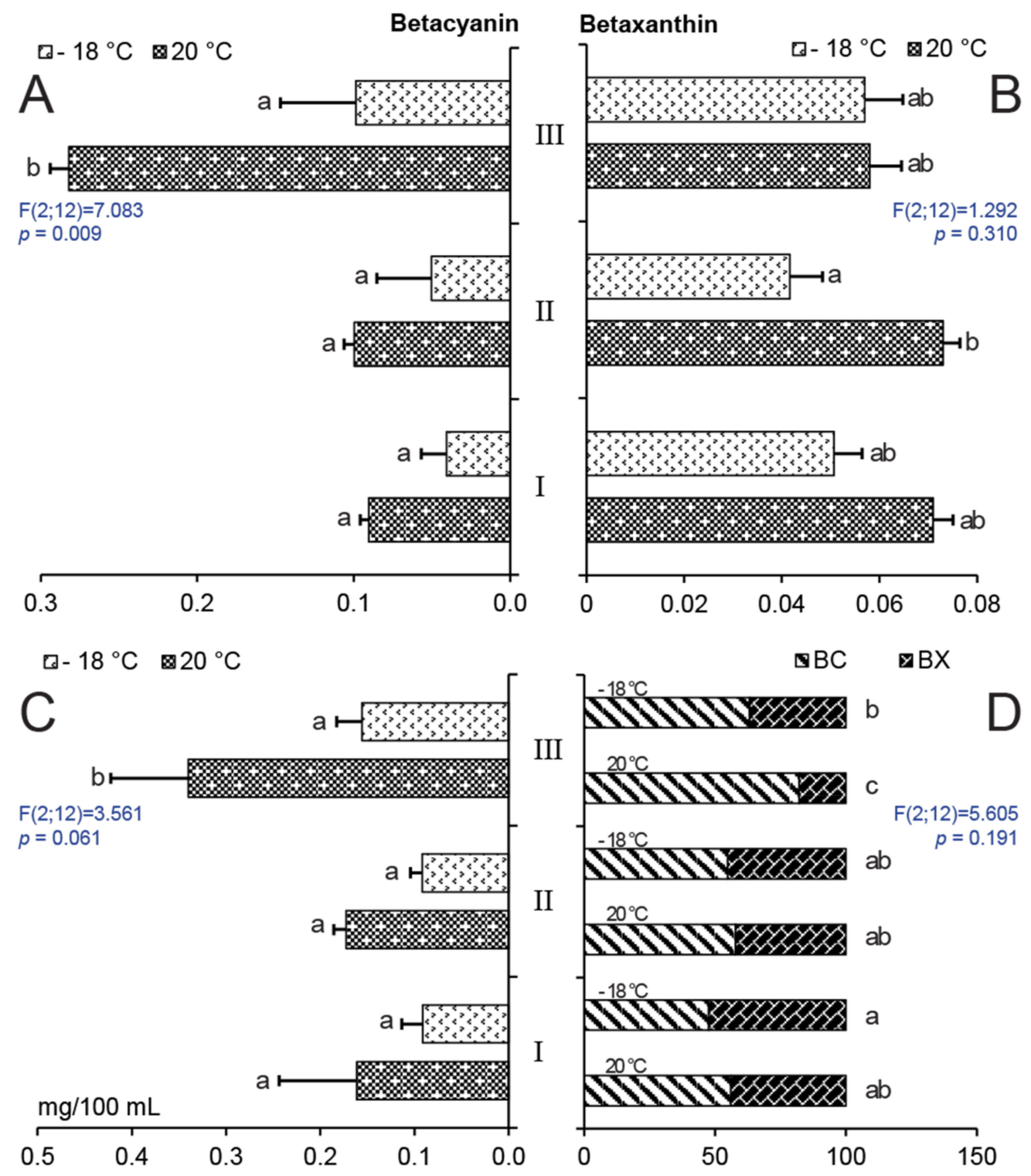

Figure 5. Contents of beet pigments. (A) BC, betacyanins, (B) BX, betaxanthins, and (C) BL, betalains, in $\mathrm{mg} / 100 \mathrm{~mL}$, and the $\mathrm{BC} / \mathrm{BX}$ percentage ratio (D) in hypocotyl extracts from Beta vulgaris subsp. maritima stored at different temperatures. I-green stems, II—slightly carmine annealed stems, and III-dark crimson stems. Bars with the same letter indicate means that are not significantly different at the 0.05 probability level according to Tukey post hoc test. Horizontal lines denote standard errors. 


\section{Discussion}

In order to better identify weed beet infestation of beet crops, an improvement on the methods described in the literature that focused on the typical colorants in beetroots was used, in which total betalain content was determined in hypocotyl extracts. In agreement with previous research $[15,28]$, higher concentrations of betacyanins and relatively low levels of betaxanthins were found in beetroot varieties LBR and MBR (Figure 1A). Other varieties had lower levels of these metabolites. Betalain synthesis is genetically fixed; however, levels can vary depending on various factors such as temperature, water content, or stage of ripening, which affect the total weight of the roots, betalain composition, and other plant characteristics [29,30]. Researchers [31] have analyzed and compared root extracts from seven different beetroot varieties. Among the different genotypes, the betalain content varied from $80 \mathrm{mg} / 100 \mathrm{~mL}$ to $130 \mathrm{mg} / 100 \mathrm{~mL}$. The betacyanins and betaxanthins ratio was in the range 1 to 1.75 . The difference in betalain concentration for individual samples of one variety was lower than that in other varieties. Our results of the analysis of hypocotyl extracts (Figure 3A) are in line with these statements, despite the lower content of betalains (MBR, $11 \mathrm{mg} / 100 \mathrm{~mL}$ ). This apparent lack of secondary metabolites might be a result of performing the analysis on hypocotyls instead of roots and by the greater ratio of pigment subgroups. This result corresponds with one study [32], where it was stated that betalain content was dependent on the type of tissue analyzed. The concentration of these compounds in root peels of variety PBR and two other beetroot varieties was higher than in the flesh and petioles. Further research confirmed a decrease in the betacyanin content toward the center of the root, while the concentration of betaxanthins did not change in individual inner layers [5].

Other cultivated groups of B. vulgaris (Altissima, Cicla, and Rapacea groups) had lower total betalain content, but their samples contained more betaxanthins than betacyanins. As stated in previous research [33], beetroot hypocotyls had higher concentrations of betacyanins than Swiss chard petioles. Plant sample coloration corresponded to the content and ratio of individual pigments. However, vulgaxanthin I may not be the only betaxanthin in the sample, as shown by the metabolite screening of Swiss chard petioles [34]. The prevalent components of betacyanins and betaxanthins can be accompanied by various similar metabolites, which can affect the final color of the tissues [35]. Apart from DBR, where the ratio of pigments should be rather used, comparing cultural varieties with $\mathrm{WB}_{\mathrm{R}}$ showed that betacyanins content in plant hypocotyls is a suitable indicator for weed beet identification. An alternative method utilizes $\mathrm{WB}_{\mathrm{G}}$, where betaxanthin concentration can also distinguish these plants from non-red varieties such as sugar beets, fodder beets, and Swiss chard.

As stated before, these particular pigments can be determined by more sensitive methods such as high performance liquid chromatography combined with photodiode array detection or mass spectrometry. Nevertheless, according to [13] spectrophotometry represents the most straightforward method for determination of betalains content. It is with agreement that these methods related to secondary metabolites in agriculture practice should not be time and cost-consuming, but they should still carry representative information [36,37]. The application of HPLC-MS ${ }^{n}$ and UV-Vis spectrometry have been investigated [32], where the latter method determined betacyanins, betaxanthins, and total content of betalains in different beetroots.

Regarding the stability of the beet product (root, juice, dye), an understanding of the factors responsible for degradation is essential for maximizing the stability of betacyanins and betaxanthins in food [38], because betalains are relatively unstable pigments [39,40]. The quantity and quality of betalains in a harvested crop can be affected by the method of processing and by the subsequent storage conditions. The culinary treatment of beetroot roots, such as boiling or roasting, also has an effect on the pigment content; however, the antioxidant activity was found to be increased in this research [41]. Another study [42] described the different conditions affecting betalain stability. The stability of these metabolites is a function of their structure, and various studies confirmed the lower lability of betacyanins compared to betaxanthins. The stability of these molecules was further increased by glycosylation. Degradation of betalains in beetroots with a subsequent change of color was mainly a 
result of $\mathrm{pH}$ values that were out of the optimal range [43] or exposure to high temperatures where first order kinetic changes are involved $[44,45]$. These natural dyes are also sensitive to water content, light, oxygen, and the presence of certain metals $[6,12]$.

Certain compounds, such as isomers of betacyanins, can be formed naturally because of external conditions or their production can be supported by artificial treatment [46]. Regarding betanin, its epimer isobetanin differs in chiral center on $C_{15}$, and has also different properties such as a prolonged retention time, but the epimer retained the same color [18]. As stated [46], the isomerization process can differ depending on the species or the betacyanin type. The loss of conjugated sugar was attributed to the activity of $\beta$-glucosidases or the effect of high temperature or low $\mathrm{pH}$ that led to the formation of labile aglycones with different $\lambda_{\max }$. Other conditions, such as $\mathrm{pH}>6$, can cause hydrolysis of the aldimine bond of betanin with production of other molecules [18]. These compounds have a different color (or no color), as is shown in Figure 6, and these changes affect the final color of the solution. Hydrolysis can also result in a loss of acyl groups in the metabolites, and the carboxyl groups of betacyanins and betalains are also susceptible to degradation [47]. However, the loss of one carboxyl group did not affect the betanidin chromophore, and the resulting molecule was even more stable [19].

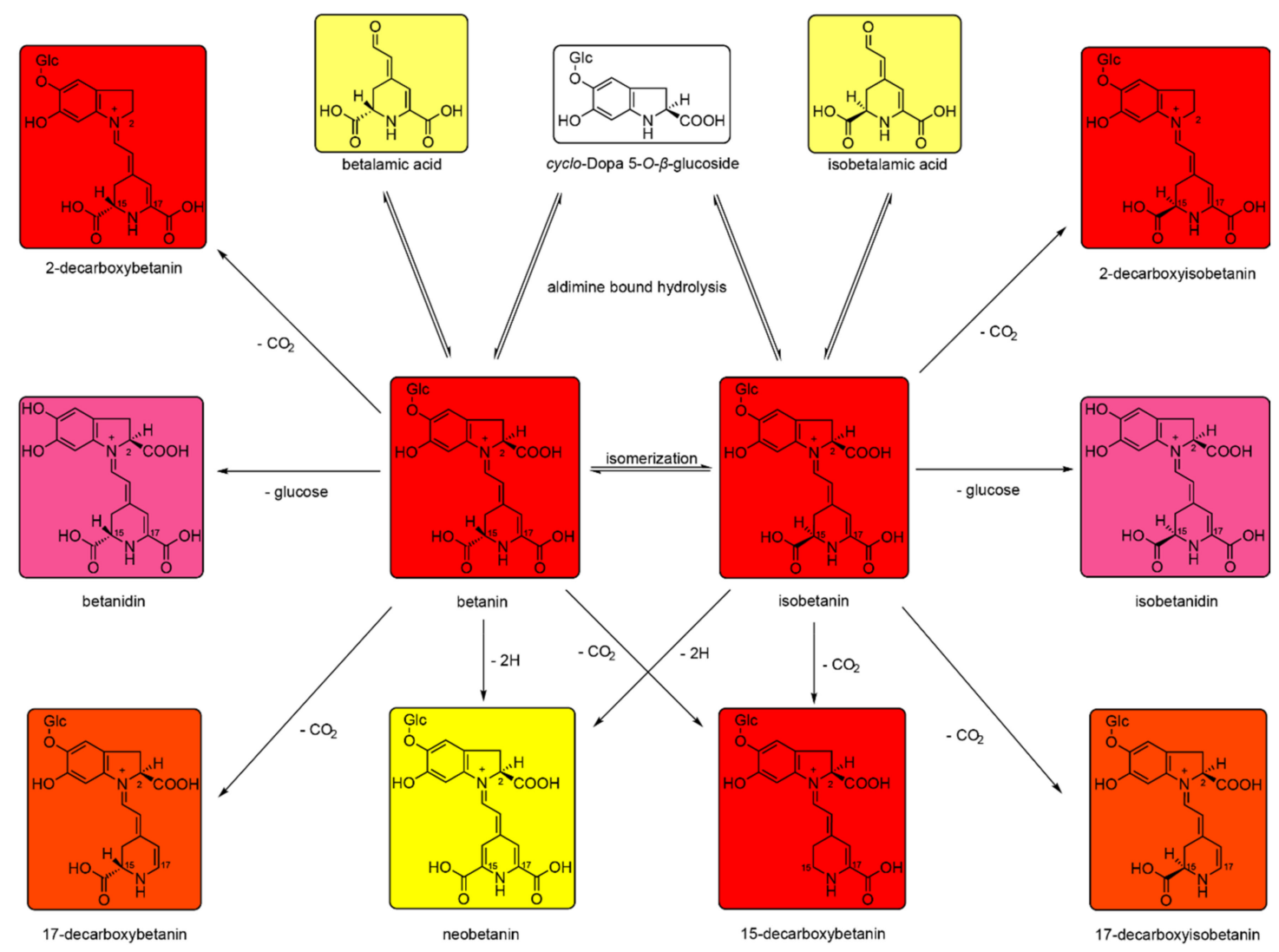

Figure 6. Chemical structure of betanin, isobetanin, their precursors, and degradation products. Adapted according to [46].

Selected representatives of the above-mentioned varieties were tested in order to determine the decrease in betanin and vulgaxanthin I equivalents under different conditions. The analysis of MFB and LBR extracts showed that brief storage at room temperature, when the samples were not exposed to elevated temperature and were away from light, did not change the content of betalains or their ratios (Figure 4C). However, one study [19] stated that several hours' exposure of samples to higher temperature had a negative effect on the stability of these metabolites in beetroots. Betanin isomerized to isobetanin in the solution and vulgaxanthin I was also degraded. Elevated temperature caused the production of neobetanin because of oxidation and the formation of a double bond between $C_{14}$ and $C_{15}$. 
Similar to betanin, this compound produces a yellow color and is present in various plant species [12]. Storage at lower temperatures [48] or protection from light [49] were presented as protective factors for betalains against degradation. While the storage of beetroots in the dark at $7^{\circ} \mathrm{C}$ for $24 \mathrm{~h}$ had no positive or negative effect on their betalain concentration, LSC (Figure 4C) appeared to have higher amounts of betacyanin and betaxanthins. It subsequently manifested in a significantly higher content of betalains. A possible explanation of this is a slight turbidity of the solution because of the decomposition of various compounds in the extract that increased the spectrophotometric readings.

However, betalains can be also regenerated. One factor in the pigment regeneration is the presence of molecules with amine groups, which form a bond with betalamic acid. In the presence of glutamine, vulgaxanthin I can be produced instead of betanin, which alters the color of the solution [46]. Regarding protection of the betalains, positive effects was described for ascorbic acid that protected betalains during the microwave-assisted extraction [50].

As mentioned above, $B$. vulgaris is not the only plant containing betalains and many papers focused on other utilizable species. This can be a case of extracts from Celosia argentea, where the betaxanthins were more stable in the form of a lyophilized powder [39].

In our experiments, storage at $-18^{\circ} \mathrm{C}$ for two weeks caused noticeable degradation of colored compounds in solutions, and it could be hypothesized that a shorter storage time might still not have a significant effect on the content of measured metabolites (Figure 4C). Study [51] reported on the effects of different drying conditions and storage on betacyanin content in Amaranthus samples. The east degradation was found in samples subjected to freeze drying and storage at $-18^{\circ} \mathrm{C}$, while the greatest loss was caused by drying in air and sun. However, the storage of WB stems at $-18^{\circ} \mathrm{C}$ caused a decrease of betacyanins concentration in sample III and betaxanthins concentration in sample II (Figure 5A,B), which resulted in a lower total betalain content (Figure 5C).

It is possible that other factors were involved in the degradation seen here. The samples with low water content were more stable [39], in comparison with our samples of WB stored in aqueous solution. Hylocereus polyrhizus extracts showed low degradation in the dark at $4{ }^{\circ} \mathrm{C}$, while exposure to light and storage at room temperature had a negative effect on the amount of colored substances and samples exposed to light that were not stabilized by ascorbic acid [52]. Betacyanins from this plant used in yogurt were also more stable than the dye, E162, and showed a certain degree of regeneration during storage at $4{ }^{\circ} \mathrm{C}$ [53]. Nevertheless, the properties of the packaging material, in which plant extract or tissue is stored, can take effect on the content of the pigments with respect to oxygen transmission, despite the storage at cold temperatures [54].

Other factors, which can take a negative effect on the pigment content of beet dyes, are enzymes, such as $\beta$-glucosidase [55], if they are not inhibited by heat treatments such as blanching [6]. The application of high-pressure carbon dioxide $(7.5 \mathrm{MPa})$ at $55^{\circ} \mathrm{C}$ effectively suppressed enzyme activity in beetroot extracts [56]. The effectiveness of this method depended on the amount of betanin in comparison with classic heat treatment. High-hydrostatic pressure $(650 \mathrm{MPa})$ was also tested as an alternative to blanching. The inhibitory effect on enzymes was less, but the concentration of betalains was higher with the shorter processing time [57]. In contrast, high pressure treatment of stalks from beetroot 'Detroit Dark Red' did not enhance betanin stability, while short heating reduced its degradation during four days of storage in plants with higher content of this metabolite, and also decreased peroxidase activity [58].

\section{Materials and Methods}

\subsection{Plant Materials (Beta Varieties and Weed Beets)}

Seeds of 11 varieties of beet crops were purchased from various seed companies in the Czech Republic. The varieties were planted in a randomized block design with three replicates each at the experimental field $\left(49^{\circ} 7886111^{\prime}\right.$ N, $15^{\circ} 3983333^{\prime}$ E) of the Czech University of Life Sciences Prague, Czech Republic (Table 1). 
The plantings were done in two-meter-long rows with row-to-row and plant-to-plant distances of 0.45 and $0.20 \mathrm{~m}$, respectively. Seeds were manually planted at a depth of $0.5 \mathrm{~cm}$ from 18 to 20 May 2015 . Each variety was represented by four experimental rows and two control rows, grown as the border rows in each replicate in order to minimize the competition for nutrients. The spacing between the sugar beet rows was $0.45 \mathrm{~m}$ and all crops received uniform nutrition, irrigation, and protection. In the rosette growth phase (leaves covering $20 \%$ of the ground), beet hypocotyls were randomly selected for chemical analysis of their betalain content. Due to the instability of betalains, the samples were cleaned from soil, mixed, divided into equal groups, and immediately processed for analysis. Each experiment was repeated three times and included 10 crop beets per replicate. The weed beets (wild beets) were randomly collected from a commercial field located at Predni Kopanina $\left(50^{\circ} 121720^{\prime}\right.$ N, $14^{\circ} 292173^{\prime}$ E), on the northwest border of Prague, twice during 2015 in the same phase as crop beets (average temperature and precipitation during vegetation period, see Table 2 ). The weed beets were immediately transported to the Plant Anatomy and Morphology Laboratory in conditions protected against heat and light. The weed beet parts used in the experiment were graded based on the color: green (I), slightly carmine annealed (II), and dark crimson (III) (Figure 5). At the first time point, extracts were prepared according same procedure and then freeze-preserved for 14 days at $-18{ }^{\circ} \mathrm{C}$. On the second date, samples were processed into extracts and used for analysis immediately. It was, therefore, possible to compare the content of the unstable betalains at the two time points. The experiment used a completely randomized block design and a two-factor factorial design. Each treatment was repeated three times and included 10 weed beets per replicate.

Table 2. Average monthly temperature levels and precipitation (Year 2015) at the experimental field ('Campus Czech University of Life Sciences,' Prague, Czech Republic) and commercial field ('Predni Kopanina,' Prague, Czech Republic) site in ${ }^{\circ} \mathrm{C}$ and $\mathrm{mm}$, respectively.

\begin{tabular}{cccc}
\hline Month & Site & Temperature & Precipitation \\
\hline \multirow{2}{*}{ April } & Campus & 8.3 & 29.7 \\
& Commercial & 8.6 & 28 \\
May & Campus & 13.2 & 33.8 \\
& Commercial & 13.7 & 44 \\
\multirow{2}{*}{ June } & Campus & 16.3 & 32.9 \\
\multirow{2}{*}{ July } & Commercial & 16.5 & 58 \\
\multirow{2}{*}{ August } & Campus & 20.9 & 68.4 \\
& Commercial & 18.5 & 75 \\
& Campus & 22.4 & 8.6 \\
& Commercial & 18.0 & 68 \\
\hline
\end{tabular}

Source: Czech Hydrometeorological Institute.

\subsection{Extraction and Analysis of Betalains}

Determination of betalain content was performed on $50 \mathrm{~g}$ samples, which consisted of the hypocotyl and $2 \mathrm{~cm}$ of rosette. The plant material was disintegrated using an immersion blender (1015 90000 Spesso; ETA) in $150 \mathrm{~mL}$ of distilled water for $1 \mathrm{~min}$. Subsequently, diatomaceous earth (Celite S; Sigma-Aldrich, Schnelldorf, Germany) was added to the suspensions and the mixture was filtered through Whatman No. 1 filter paper at low pressure. The filtrate was washed with distilled water until the liquid passing the filter was clear. The merged and measured volumes of water extracts. The water extracts were centrifuged at lab temperature by 10,000× $g$ on MPW-251 centrifuge (MPW Med. Instruments, Warsaw, Poland) for $15 \mathrm{~min}$ and supernatants were filtered through a $0.45 \mu \mathrm{m}$ membrane filter. The final solutions were analyzed immediately (Figures 1 and 2 ) or stored at $22^{\circ} \mathrm{C}, 7^{\circ} \mathrm{C}$, or $-18^{\circ} \mathrm{C}$ according to the test conditions (Figures 4 and 5). Spectrophotometric analysis of extracts, prepared from different varieties as adapted from [59], was performed using a HELIOS $\gamma$ spectrophotometer (ThermoFisher Scientific, Waltham, MA, USA). Samples with too high concentrations were diluted with phosphate buffer $(0.05 \mathrm{M}, \mathrm{pH}$ 6.5) to an optimal absorbance of 0.4-0.5 AU. Phosphate buffer was 
used as the blank. Betalain absorption was determined at three different wavelengths. Betanin has its $A_{\max }$ at $538 \mathrm{~nm}$, whereas the $A_{\max }$ of vulgaxanthin $\mathrm{I}$ is at $476 \mathrm{~nm}$. Measurements at $600 \mathrm{~nm}$ were used to correct for the presence of impurities. Absorbance peaks at 538 and $476 \mathrm{~nm}$ reflect similar structures and they can be used for analysis of betalains without isolation of specific pigments. Absorption spectra (350-750 nm in $50 \mathrm{~nm}$ steps) were measured for LBR beetroot varieties only (Figure 3B). The absorption of betanin constituent ( $\mathrm{A}_{\text {Betanin }}$ ) was determined after subtracting $\mathrm{A}_{600}$ (Equation (1)). The calculation for absorbance of impurities is presented in Equation (2). Betanin also absorbs light at $476 \mathrm{~nm}$, and this effect is included in Equation (3) for the determination of vulgaxanthin absorption (Avulgaxanthin I).

$$
\begin{gathered}
\mathrm{A}_{\text {Betanin }}=1.095 \times\left(\mathrm{A}_{538}-\mathrm{A}_{600}\right) \\
\mathrm{A}_{\text {Impurities }}=\mathrm{A}_{538}-\mathrm{A}_{\text {Betanin }} \\
\mathrm{A}_{\text {Vulgaxanthin I }}=\frac{\mathrm{A}_{476}-\mathrm{A}_{\text {Impurities }}-\mathrm{A}_{\text {Betanin }}}{3.1}
\end{gathered}
$$

Absorption of betanin at $476 \mathrm{~nm}$ is not constant, and changes according to the concentration; therefore, the ratio $\mathrm{A}_{538} / \mathrm{A}_{476}$ was utilized for the calculations and its value was 3.1. Vulgaxanthin I does not absorb light at $538 \mathrm{~nm}$ [59]. The concentrations of betacyanins and betaxanthins were determined using absorbance $\mathrm{A}^{1 \%}$ and the corresponding dilution factor. $\mathrm{A}^{1 \%}$ is the extinction coefficient of a $1 \%$ solution $\left(\mathrm{A}_{\text {Betanin }}^{1 \%}=1120, \mathrm{~A}_{\text {Vulgaxanthin I }}^{1 \%}=750\right)$, converted to units of $\mathrm{mg}$ per $100 \mathrm{~mL}$ with regard to the volumes of the tested extracts. The total content of betalains was calculated as the sum of betacyanins and betaxanthins (Equation (4)):

$$
\begin{aligned}
c_{\text {Betanin }} & =\frac{25 \times A_{\text {Betanin }}}{1120} \\
c_{\text {Vulgaxanthin I }} & =\frac{25 \times A_{\text {Vulgaxanthin I }}}{750}
\end{aligned}
$$

There are other pigments with structures similar to betanin and vulgaxanthin I, but these two metabolites represent 95\% of the betalain content. According to [59], the other pigments have similar absorbance maxima, but their contribution is negligible.

\subsection{Statistical Analysis}

A mixed-model procedure, with a repeated statement for each parameter, was used to analyze the data set. Data from each variety and weed beets were analyzed using a Factorial ANOVA model with a post-hoc test of differences among combinations of experimental factors using the Tukey HSD method. All statistical tests presented in this study were performed using a Statistica 13.5 (StatSoft Inc., Tulsa, OK, USA) software package.

\section{Conclusions}

In conclusion, simple spectrophotometric measurements and calculations of the total betalain content and the percentages of specific components, such as betacyanins and betaxanthins, in samples of 11 cultivated and one wild variety of B. vulgaris showed that these parameters were suitable for preliminary variety verification. This method can also be utilized for the identification of weed beet infestation in beet fields. Short-term storage at normal and lower temperatures generally did not change the contents of these compounds, and samples can be stored for a certain time before analysis without misrepresentation. Further qualitative and quantitative analysis of specific pigment molecules from $B$. vulgaris L. genotypes would bring more detailed information regarding crop and wild beets.

Author Contributions: Conceptualization, M.S. and J.K.; methodology, M.S. and J.K.; software, M.S. and P.V.; formal analysis, M.S. and J.K.; investigation, H.S., M.T.-U.-A., and V.H.; writing-original draft preparation, M.S. and J.K.; visualization, M.S. and P.V.; supervision, V.H.; funding acquisition, M.S. and V.H. All authors have read and agreed to the published version of the manuscript. 
Funding: This work was supported by the Ministry of Education, Youth and Sports of the Czech Republic grant number (S grant of MSMT CR).

Acknowledgments: We thank Romana Vinduskova and Silvie Vlkova for their valuable help with experiment processing.

Conflicts of Interest: The authors declare no conflict of interest.

\section{References}

1. FAO FAOSTAT_Food and Agriculture Organization of the United. 2019. Available online: http://www.fao. org/faostat/en/\#home (accessed on 10 April 2020).

2. Pyo, Y.H.; Lee, T.C.; Logendra, L.; Rosen, R.T. Antioxidant activity and phenolic compounds of Swiss chard (Beta vulgaris subspecies cycla) extracts. Food Chem. 2004, 85, 19-26. [CrossRef]

3. Brockington, S.F.; Walker, R.H.; Glover, B.J.; Soltis, P.S.; Soltis, D.E. Complex pigment evolution in the Caryophyllales. New Phytol. 2011, 190, 854-864. [CrossRef]

4. Cai, Y.Z.; Sun, M.; Corke, H. Characterization and application of betalain pigments from plants of the Amaranthaceae. Trends Food Sci. Technol. 2005, 16, 370-376. [CrossRef]

5. Sawicki, T.; Baczzek, N.; Wiczkowski, W. Betalain profile, content and antioxidant capacity of red beetroot dependent on the genotype and root part. J. Funct. Foods 2016, 27, 249-261. [CrossRef]

6. Azeredo, H.M.C. Betalains: Properties, sources, applications, and stability-A review. Int. J. Food Sci. Technol. 2009, 44, 2365-2376. [CrossRef]

7. Miguel, M. Betalains in Some Species of the Amaranthaceae Family: A Review. Antioxidants 2018, 7, 53. [CrossRef]

8. Polturak, G.; Aharoni, A. "La Vie en Rose": Biosynthesis, Sources, and Applications of Betalain Pigments. Mol. Plant 2018, 11, 7-22. [CrossRef]

9. Wybraniec, S.; Jerz, G.; Gebers, N.; Winterhalter, P. Ion-pair high-speed countercurrent chromatography in fractionation of a high-molecular weight variation of acyl-oligosaccharide linked betacyanins from purple bracts of Bougainvillea glabra. J. Chromatogr. B 2010, 878, 538-550. [CrossRef]

10. Jackman, R.L.; Smith, J.L. Anthocyanins and betalains. In Natural Food Colorants; Hendry, G.A.F., Houghton, J.D., Eds.; Springer US: Boston, MA, USA, 1996; pp. 244-309. ISBN 978-1-4615-2155-6.

11. Stintzing, F.C.; Schieber, A.; Carle, R. Identification of betalains from yellow beet (Beta vulgaris L.) and cactus pear [Opuntia ficus-indica (L.) Mill.] by high-performance liquid chromatography-electrospray ionization mass spectrometry. J. Agric. Food Chem. 2002, 50, 2302-2307. [CrossRef]

12. Esquivel, P. Betalains. In Handbook on Natural Pigments in Food and Beverages: Industrial Applications for Improving Food Color; Elsevier: Amsterdam, The Netherlands, 2016; pp. 81-99. ISBN 9780081003923.

13. Belhadj Slimen, I.; Najar, T.; Abderrabba, M. Chemical and Antioxidant Properties of Betalains. J. Agric. Food Chem. 2017, 65, 675-689. [CrossRef]

14. Cai, Y.; Sun, M.; Corke, H. Antioxidant activity of betalains from plants of the Amaranthaceae. J. Agric. Food Chem. 2003, 51, 2288-2294. [CrossRef] [PubMed]

15. Czapski, J.; Mikołajczyk, K.; Kaczmarek, M. Relationship between antioxidant capacity of red beet juice and contents of its betalain pigments. Polish J. Food Nutr. Sci. 2009, 59, 119-122.

16. Pátkai, G.; Barta, J. Decomposition of betacyanins and betaxanthins by heat and pH changes. Nahr. Food 1996, 40, 267-270. [CrossRef]

17. Huang, A.S.; Elbe, J.H.V. Kinetics of the Degradation and Regeneration of Betanine. J. Food Sci. 1985, 50, 1115-1120. [CrossRef]

18. Schwartz, S.J.; von Elbe, J.H. Identification of betanin degradation products. Z. Lebensm. Unters. Forsch. 1983, 176, 448-453. [CrossRef]

19. Herbach, K.M.; Stintzing, F.C.; Carle, R. Impact of thermal treatment on color and pigment pattern of red beet (Beta vulgaris L.) preparations. J. Food Sci. 2004, 69, C491-C498. [CrossRef]

20. Bartsch, D.; Ellstrand, N.C. Genetic evidence for the origin of Californian wild beets (genus Beta). Theor. Appl. Genet. 1999, 99, 1120-1130. [CrossRef]

21. LONGDEN, P.C. Effects of increasing weed-beet density on sugar-beet yield and quality. Ann. Appl. Biol. 1989, 114, 527-532. [CrossRef]

22. Richardson, K.L.; Hellier, B.C.; Sinha, K. Characterization of wild Beta populations in and adjacent to sugar beet fields in the Imperial Valley, California. Genet. Resour. Crop Evol. 2016, 63, 305-314. [CrossRef] 
23. Sester, M.; Dürr, C.; Darmency, H.; Colbach, N. Evolution of weed beet (Beta vulgaris L.) seed bank: Quantification of seed survival, dormancy, germination and pre-emergence growth. Eur. J. Agron. 2006, 24, 19-25. [CrossRef]

24. Biancardi, E.; Panella, L.W.; Lewellen, R.T.; Biancardi, E.; Panella, L.W.; Lewellen, R.T. Morphology, Physiology, and Ecology. In Beta maritima; Springer: New York, NY, USA, 2012; pp. 85-136. ISBN 978-1-4614-0842-0.

25. Tricault, Y.; Darmency, H.; Colbach, N. Identifying key components of weed beet management using sensitivity analyses of the GeneSys-Beet model in GM sugar beet. Weed Res. 2009, 49, 581-591. [CrossRef]

26. Skalický, M.; Tůma, J.; Novák, J.; Pulkrábek, J.; Steklová, J. Phenotype variability of weed beet (Beta vulgaris L.). Cereal Res. Commun. 2007, 35, 1077-1080. [CrossRef]

27. European Commission European Plant Variety Database. Available online: http://ec.europa.eu/food/ plant/plant_propagation_material/plant_variety_catalogues_databases/search/public/index.cfm?event= SearchForm\&ctl_type=A (accessed on 10 April 2020).

28. Gasztonyi, M.N.; Daood, H.; Hájos, M.T.; Biacs, P. Comparison of red beet (Beta vulgaris var conditiva) varieties on the basis of their pigment components. J. Sci. Food Agric. 2001, 81, 932-933. [CrossRef]

29. Nizioł-Łukaszewska, Z.; Gawęda, M. Selected Indicators of the Root Quality of Fifteen Cultivars of Red Beet (Beta vulgaris L.). J. Hortic. Res. 2015, 23, 65-74. [CrossRef]

30. Montes-Lora, S.; Rodríguez-Pulido, F.J.; Cejudo-Bastante, M.J.; Heredia, F.J. Implications of the Red Beet Ripening on the Colour and Betalain Composition Relationships. Plant Foods Hum. Nutr. 2018, 73, $216-221$. [CrossRef]

31. Wruss, J.; Waldenberger, G.; Huemer, S.; Uygun, P.; Lanzerstorfer, P.; Müller, U.; Höglinger, O.; Weghuber, J. Compositional characteristics of commercial beetroot products and beetroot juice prepared from seven beetroot varieties grown in Upper Austria. J. Food Compos. Anal. 2015, 42, 46-55. [CrossRef]

32. Slatnar, A.; Stampar, F.; Veberic, R.; Jakopic, J. HPLC-MSn Identification of Betalain Profile of Different Beetroot (Beta vulgaris L. ssp. vulgaris) Parts and Cultivars. J. Food Sci. 2015, 80, 1952-1958. [CrossRef]

33. Kugler, F.; Graneis, S.; Stintzing, F.C.; Carle, R. Studies on betaxanthin profiles of vegetables and fruits from the Chenopodiaceae and Cactaceae. Z. Naturforsch. Sect. C J. Biosci. 2007, 62, 311-318. [CrossRef]

34. Kugler, F.; Stintzing, F.C.; Carle, R. Evaluation of the antioxidant capacity of betalainic fruits and vegetables. J. Appl. Bot. Food Qual. 2007, 81, 69-76.

35. Stintzing, F.C.; Carle, R. Betalains-Emerging prospects for food scientists. Trends Food Sci. Technol. 2007, 18, 514-525. [CrossRef]

36. Lombard, K.A.; Geoffriau, E.; Peffley, E. Flavonoid Quantification in Onion by Spectrophotometric and High Performance Liquid Chromatography Analysis. HortScience 2002, 37, 682-685. [CrossRef]

37. Vrhovsek, U.; Mattivi, F.; Waterhouse, A.L. Analysis of red wine phenolics: Comparison of HPLC and spectrophotometric methods. Vitis 2001, 40, 87-91.

38. Güneşer, O. Pigment and color stability of beetroot betalains in cow milk during thermal treatment. Food Chem. 2016, 196, 220-227. [CrossRef] [PubMed]

39. Cai, Y.; Sun, M.; Schliemann, W.; Corke, H. Chemical stability and colorant properties of betaxanthin pigments from Celosia argentea. J. Agric. Food Chem. 2001, 49, 4429-4435. [CrossRef]

40. Fernández-López, J.A.; Angosto, J.M.; Giménez, P.J.; León, G. Thermal Stability of Selected Natural Red Extracts Used as Food Colorants. Plant Foods Hum. Nutr. 2013, 68, 11-17. [CrossRef]

41. Ravichandran, K.; Saw, N.M.M.T.; Mohdaly, A.A.A.; Gabr, A.M.M.; Kastell, A.; Riedel, H.; Cai, Z.; Knorr, D.; Smetanska, I. Impact of processing of red beet on betalain content and antioxidant activity. Food Res. Int. 2013, 50, 670-675. [CrossRef]

42. Herbach, K.M.; Stintzing, F.C.; Carle, R. Stability and color changes of thermally treated betanin, phyllocactin, and hylocerenin solutions. J. Agric. Food Chem. 2006, 54, 390-398. [CrossRef]

43. Mikołajczyk-Bator, K.; Czapski, J. Effect of pH Changes on Antioxidant Capacity and the Content of Betalain Pigments during the Heating of a Solution of Red Beet Betalains. Polish J. Food Nutr. Sci. 2017, 67, 123-128. [CrossRef]

44. Herbach, M.K.; Stintzing, F.C.; Carle, R. Thermal degradation of betacyanins in juices from purple pitaya [Hylocereus polyrhizus (Weber) Brittonv \& Rose] monitored by high-performance liquid chromatography-tandem mass spectometric analyses. Eur. Food Res. Technol. 2004, 219, 377-385. 
45. Narkprasom, K.; Wang, S.-P.; Hsiao, S.-M.; Tsai, P.-J. Kinetics of Color Loss of Djulis (Chenopodium formosanum Koidz.) Extracts during Storage in Different Concentrations of Alcohol and Temperature. APCBEE Procedia 2012, 2, 32-36. [CrossRef]

46. Herbach, K.M.; Stintzing, F.C.; Carle, R. Betalain stability and degradation-Structural and chromatic aspects. J. Food Sci. 2006, 71, R41-R50. [CrossRef]

47. Herbach, K.M.; Stintzing, F.C.; Carle, R. Identification of heat-induced degradation products from purified betanin, phyllocactin and hylocerenin by high-performance liquid chromatography/electrospray ionization mass spectrometry. Rapid Commun. Mass Spectrom. 2005, 19, 2603-2616. [CrossRef] [PubMed]

48. Caldas-Cueva, J.P.; Morales, P.; Ludeña, F.; Betalleluz-Pallardel, I.; Chirinos, R.; Noratto, G.; Campos, D. Stability of Betacyanin Pigments and Antioxidants in Ayrampo (Opuntia soehrensii Britton and Rose) Seed Extracts and as a Yogurt Natural Colorant. J. Food Process. Preserv. 2016, 40, 541-549. [CrossRef]

49. Moßhammer, M.R.; Maier, C.; Stintzing, F.C.; Carle, R. Impact of thermal treatment and storage on color of yellow-orange cactus pear (Opuntia ficus-indica [L.] Mill. cv. 'Gialla') juices. J. Food Sci. 2006, 71, C400-C406. [CrossRef]

50. Cardoso-Ugarte, G.A.; Sosa-Morales, M.E.; Ballard, T.; Liceaga, A.; San Martín-González, M.F. Microwave-assisted extraction of betalains from red beet (Beta vulgaris). LWT Food Sci. Technol. 2014, 59, 276-282. [CrossRef]

51. Cai, Y.Z.; Corke, H. Effect of postharvest treatments on Amaranthus betacyanin degradation evaluated by visible/near-infrared spectroscopy. J. Food Sci. 2001, 66, 1112-1118. [CrossRef]

52. Woo, K.K.; Ngou, F.H.; Ngo, L.S.; Soong, W.K.; Tang, P.Y. Stability of betalain pigment from red dragon fruit (Hylocereus polyrhizus). Am. J. Food Technol. 2011, 6, 140-148. [CrossRef]

53. Gengatharan, A.; Dykes, G.A.; Choo, W.S. The effect of $\mathrm{pH}$ treatment and refrigerated storage on natural colourant preparations (betacyanins) from red pitahaya and their potential application in yoghurt. LWT Food Sci. Technol. 2017, 80, 437-445. [CrossRef]

54. Sonar, C.R.; Rasco, B.; Tang, J.; Sablani, S.S. Natural color pigments: Oxidative stability and degradation kinetics during storage in thermally pasteurized vegetable purees. J. Sci. Food Agric. 2019, 99, 5934-5945. [CrossRef]

55. Strack, D.; Vogt, T.; Schliemann, W. Recent advances in betalain research. Phytochemistry 2003, 62, $247-269$. [CrossRef]

56. Liu, X.; Gao, Y.; Xu, H.; Hao, Q.; Liu, G.; Wang, Q. Inactivation of peroxidase and polyphenol oxidase in red beet (Beta vulgaris L.) extract with continuous high pressure carbon dioxide. Food Chem. 2010, 119, 108-113. [CrossRef]

57. Paciulli, M.; Medina-Meza, I.G.; Chiavaro, E.; Barbosa-Cánovas, G.V. Impact of thermal and high pressure processing on quality parameters of beetroot (Beta vulgaris L.). LWT Food Sci. Technol. 2016, 68, 98-104. [CrossRef]

58. Dos Santos, C.D.; Ismail, M.; Cassini, A.S.; Marczak, L.D.F.; Tessaro, I.C.; Farid, M. Effect of thermal and high pressure processing on stability of betalain extracted from red beet stalks. J. Food Sci. Technol. 2018, 55, 568-577. [CrossRef] [PubMed]

59. Von Elbe, J.H. Betalains. Curr. Protoc. Food Anal. Chem. 2001, 00, F3.1.1-F3.1.7. [CrossRef]

Sample Availability: Samples of the compounds are not available from the authors.

Publisher's Note: MDPI stays neutral with regard to jurisdictional claims in published maps and institutional affiliations.

(C) 2020 by the authors. Licensee MDPI, Basel, Switzerland. This article is an open access article distributed under the terms and conditions of the Creative Commons Attribution (CC BY) license (http://creativecommons.org/licenses/by/4.0/). 